\title{
Effects of non-steroidal anti-inflammatory drug-activated gene-1 on Ganoderma lucidum polysaccharides-induced apoptosis of human prostate cancer PC-3 cells
}

\author{
KAIKAI WU, KUN NA, DIAN CHEN, YUJIE WANG, HAITAO PAN and XINGYA WANG \\ College of Pharmaceutical Sciences, Zhejiang Chinese Medical University, Hangzhou, Zhejiang 310053, P.R. China
}

Received February 21, 2018; Accepted June 14, 2018

DOI: $10.3892 /$ ijo.2018.4578

\begin{abstract}
Ganoderma lucidum polysaccharides (GLP) has been demonstrated to elicit antitumorigenic and proapoptotic activities in cancer; however, the molecular mechanisms underlying the anticancer effects of GLP have yet to be elucidated. Non-steroidal anti-inflammatory drug-activated gene-1 (NAG-1) has been reported to exert proapoptotic effects and therefore, may serve an important role in cancer prevention. The present study aimed to elucidate the molecular mechanism by which GLP stimulates anticancer activity in human prostate cancer ( $\mathrm{PCa}$ ) $\mathrm{PC}-3$ cells. In addition, the role of NAG-1 in GLP-induced cancer inhibition was examined. The results of the present study demonstrated that GLP significantly inhibited cell viability in a time- and dose-dependent manner in PC-3 cells. Flow cytometry indicated that GLP induced late apoptosis, which was accompanied by poly (ADP-ribose) polymerase 1 (PARP) cleavage, and inhibition of pro-caspase-3, -6 and -9 protein expression. Furthermore, it was observed that the expression levels of NAG-1, and its transcriptional factor early growth response-1, were upregulated in a time- and dose-dependent manner upon GLP treatment. The results of a luciferase assay demonstrated that GLP induced the promoter activity of NAG-1, thus indicating that NAG-1 may be transcriptionally regulated by GLP. The secretion of NAG-1 proteins into the cell culture medium was also upregulated upon GLP treatment. Furthermore, inhibition of NAG-1 expression by small interfering RNA significantly, but not completely, prevented GLP-induced apoptosis, and reversed the effects of GLP on PARP and pro-caspase expression. It was further demonstrated that GLP inhibited the
\end{abstract}

Correspondence to: Dr Xingya Wang, College of Pharmaceutical Sciences, Zhejiang Chinese Medical University, 548 Binwen Road, Hangzhou, Zhejiang 310053, P.R. China

E-mail: xywang@zcmu.edu.cn

Abbreviations: GLP, Ganoderma lucidum polysaccharide; NAG-1, nonsteroidal anti-inflammatory drug-activated gene-1; EGR-1, early growth response-1

Key words: GLP, prostate cancer, apoptosis, NAG-1 phosphorylation of protein kinase B and mitogen-activated protein kinase/extracellular signal-regulated kinase signaling in PC-3 cells. The present study is the first, to the best of our knowledge, to report that GLP may induce apoptosis of PCa cells, which is partially mediated through NAG-1 induction. The present findings may be helpful in elucidating the anticancer mechanisms of GLP through NAG-1 induction for its chemopreventive potential in $\mathrm{PCa}$.

\section{Introduction}

Prostate cancer $(\mathrm{PCa})$ is the most common non-skin malignancy in males and the second leading cause of cancer-associated mortality in men in the United States. It has been estimated that $\sim 161,360$ new cases and $\sim 26,730$ cases of PCa-associated mortality occurred in the United States in 2017 (1). However, the pathogenesis of PCa has not yet been completely elucidated. PCa has a complex etiology; numerous risk factors, including age, ethnicity, obesity and family history, are most frequently reported to be associated with the disease (2). Other factors, including diet, inflammation and environment, may also contribute to the development and progression of $\mathrm{PCa}$ (3). One important characteristic of PCa is that it usually progresses from androgen-dependent to androgen-independent phenotypes with highly metastatic properties $(3,4)$. Early-stage $\mathrm{PCa}$, which is usually confined to the prostate gland, may be cured by surgery, whereas advanced-stage PCa that has metastasized to various organs is typically treated by androgen ablation methods (5). It has been speculated that PCa may develop into hormone-refractory tumors due to alternative cellular processes that favor cancer cell proliferation and/or the accumulation of mutations in the androgen receptor (6). Hormone-refractory $\mathrm{PCa}$ is usually incurable and eventually fatal. Besides surgery and hormonal treatment, radiotherapy and chemotherapy are also used to treat all stages of PCa, although they frequently lead to unwanted side effects and decreased quality of life for patients. Therefore, the development of safe and effective novel anti-PCa medicines remains a focus of research.

PC-SPES is an herbal mixture previously marketed by Botanic Lab (Brea, CA, USA) that has been used as an alternative treatment for patients with $\mathrm{PCa}$ (7). Numerous in vitro and in vivo studies have reported that PC-SPES may exert promising anticancer activities against PCa (8-10). In addition, PC-SPES has been successfully tested, with 
promising results in phase II clinical trials, as an effective agent in the treatment of advanced PCa with very minimal side effects (11-16). Ganoderma lucidum, also termed Lingzhi or Reshi, is one of eight herbs used in PC-SPES. However, PC-SPES was withdrawn from the market in 2002 following identification of contamination with prescription drugs, e.g. warfarin $(17,18)$. Although PC-SPES was removed from the market, studies focusing on novel formulas, and examining the anticancer activity and molecular mechanisms underlying individual components of PC-SPES are of critical importance. In particular, further research is required to pinpoint the exact mechanism of action of each component against $\mathrm{PCa}$, including G. lucidum.

G. lucidum has been the most popular medicinal mushroom used in Traditional Chinese Medicine (TCM) for $>2,000$ years, and it has previously been used to promote vitality and longevity in East Asia (19). Recently, it has been hypothesized to possess anticancer activities against numerous types of cancer (19). Previous studies have suggested that G. lucidum may inhibit PCa cell proliferation, angiogenesis and migration, induce apoptosis and cell cycle arrest, and interfere with androgen receptor function $(6,20,21)$. In the past few decades, several bioactive chemical substances, including polysaccharides and triterpenoids extracted from the fruiting bodies, cultured mycelia and spores of G. lucidum, have been reported to be responsible for its anticancer activity. Numerous studies have aimed to elucidate the molecular mechanism of action against cancer of all the major bioactive compounds, including polysaccharides and triterpenoids $(6,20,21)$. In particular, G. lucidum polysaccharides (GLP) have been demonstrated to exert anticarcinogenic effects, which may be due to their immunomodulatory and apoptotic activity (22). However, the exact molecular target or signaling pathway of GLP against $\mathrm{PCa}$ is currently unclear.

Non-steroidal anti-inflammatory drug (NSAID)-activated gene-1 (NAG-1), also termed growth differentiation factor-15 (GDF15) or macrophage inhibitory cytokine 1, is a divergent member of the transforming growth factor- $\beta$ superfamily. NAG-1 serves a complex, although poorly understood, role in normal physiology and in numerous human diseases, including cancer (23). It has been demonstrated that several tumor suppressor pathways, including p53, glycogen synthase kinase-3 $\beta$ and early growth response-1 (EGR-1), serve as upstream factors in NAG-1 transcriptional induction $(22,23)$; NAG-1 may also be induced by various anticancer drugs or natural compounds. NAG-1 overexpression is able to inhibit the development of prostate tumors in animal models (24). Further laboratory and clinical evidence suggested that NAG-1 may serve an anticarcinogenic role in the early stage of carcinogenesis, and a protumorigenic role in the late stage of carcinogenesis, as reviewed by Wang et al (23). Previous studies have also suggested that NAG-1 is proapoptotic, and thus inhibits cancer cell proliferation (25-28). Recently, it was reported that water extracts of G. lucidum (primarily containing GLP) inhibit colorectal cancer carcinogenesis and induce NAG-1 (22). However, whether NAG-1 may be induced in PCa cells by GLP, and its potential role in the anti-PCa effects of GLP, remains unknown.

The present study assessed the effects and mechanism of GLP extracted from sporoderm-broken spores of G. lucidum on PCa, and examined the role of NAG-1 in androgenindependent and highly metastatic PC-3 cells. These data suggested that GLP was effective against PCa proliferation via NAG-1 mediated apoptosis. To the best of our knowledge, the present study is the first to examine the role of NAG-1 in GLP-induced anticancer effects in PCa. The present results may aid in elucidating the anticancer mechanisms of GLP.

\section{Materials and methods}

Materials. MTT was obtained from HXBIO (Hangzhou, China). Hoechst 33342 was obtained from Invitrogen (Thermo Fisher Scientific, Inc., Waltham, MA, USA). Dulbecco's modified Eagle's medium (DMEM) was purchased from Gibco (Thermo Fisher Scientific, Inc.). The fluorescein isothiocyanate (FITC) Annexin V apoptosis detection kit and propidium iodide (PI) staining kit were purchased from BD Pharmingen; BD Biosciences (San Jose, CA, USA). Polyclonal $\beta$-actin (cat. no. 4967S), poly(ADP-ribose) polymerase 1 (PARP) (cat. no. 9542S), caspase-3 (cat. no. 9665), caspase-6 (cat. no. 9762), caspase-9 (cat. no. 9508), phosphorylated (p)-extracellular signal-regulated kinase (Erk)1/2 (cat. no. 9101S), Erk1/2 (cat. no. 9102S), p-protein kinase B (Akt) (cat. no. 9271S), Akt (cat. no. 9272S), EGR-1 (cat. no. 4153) and horseradish peroxidase-conjugated antirabbit immunoglobulin $\mathrm{G}$ ( $\mathrm{IgG}$, cat. no. 7074) and anti-mouse IgG (cat. no. 7076) antibodies were purchased from Cell Signaling Technology, Inc. (Danvers, MA, USA). The NAG-1 polyclonal rabbit antibody was generated in Dr Eling's laboratory (Laboratory of Molecular Carcinogenesis, National Institute of Environmental Health Sciences, Durham, NC, USA), as previously described (29). The Quantikine Human GDF15/NAG-1 ELISA kit (cat. no. DY957) was purchased from R\&D Systems, Inc. (Minneapolis, MN, USA). The RNA extraction kit was obtained from Aidlab Biotechnologies, Co., Ltd. (Beijing, China). NAG-1 small interfering (si) RNA (cat. no. M-019875-01) and control siRNA (cat. no. D-00120613) were obtained from Dharmacon, Inc. (Lafayette, CO, USA). Lipofectamine $^{\circledR} 2000$ transfection reagent was purchased from Invitrogen (Thermo Fisher Scientific, Inc.). The DualLuciferase assay kit was purchased from Promega Corp. (Madison, WI, USA). The iScript cDNA synthesis kit and SYBR Master Mix were purchased from Bio-Rad Laboratories, Inc. (Hercules, CA, USA). The bicinchoninic acid (BCA) assay kit was purchased from Pierce (Thermo Fisher Scientific, Inc.). The Western Lightening ${ }^{\mathrm{TM}}$ Plus-ECL, enhanced chemiluminescence substrate assay kit was purchased from PerkinElmer, Inc. (Waltham, MA, USA).

GLP preparation. Powder from sporoderm-broken spores of G. lucidum was obtained from Zhejiang Shouxiangu Pharmaceutical Co., Ltd. (Wuyi, China). Polysaccharides were extracted from the powder of sporoderm-broken spores of G. lucidum using the hot water extraction method, as previously described (22). Following extraction, the GLP was purified and dissolved in DMEM at $20 \mathrm{mg} / \mathrm{ml}$ as the stock solution.

Cell culture. Human PCa cell lines PC-3, DU145 and LNCaP, and the non-cancerous cell lines RWPE-1 and PrEC, were 
purchased from the American Type Culture Collection (ATCC; Manassas, VA, USA). Cells were maintained in an incubator containing $5 \% \mathrm{CO}_{2}$ at $37^{\circ} \mathrm{C}$ in DMEM supplemented with $10 \%$ fetal bovine serum (FBS; Gemini Bio Products, West Sacramento, CA, USA).

MTT assay. The MTT assay was used to assess cell viability. Briefly, PC-3, DU145, LNCaP, RWPE-1 and PrEC cells were seeded in 96 -well plates at $1 \times 10^{4}$ cells/well and incubated at $37^{\circ} \mathrm{C}$ in DMEM until the cells reached $60 \%$ confluence. Subsequently, PC-3, DU145 and LNCaP PCa cells were treated with various concentrations of GLP $(0,1.25,2.5,5$ and $10 \mathrm{mg} / \mathrm{ml}$ ) for 24,48 and $72 \mathrm{~h}$, RWPE- 1 and PrEC and nonmalignant prostate cells were treated for $48 \mathrm{~h}$. Subsequently, MTT solution $(5 \mathrm{mg} / \mathrm{ml})$ was added to each well and incubated for $4 \mathrm{~h}$ at $37^{\circ} \mathrm{C}$, after which, the supernatants were discarded and $150 \mu \mathrm{l}$ dimethyl sulfoxide (DMSO) was added to dissolve the remaining water-insoluble formazan crystals. After a 10-min incubation, the absorbance was determined using a multi-well plate reader (BioTek Instruments, Inc., Winooski, VT, USA) at $490 \mathrm{~nm}$. All experiments were repeated at least three times.

Hoechst 33342 staining. Apoptosis was visualized according to nuclear morphological alterations using the fluorescent dye Hoechst 33342. When PC-3 cells had been treated with $\operatorname{GLP}(0,1.25,2.5,5$ and $10 \mathrm{mg} / \mathrm{ml})$ for $48 \mathrm{~h}$, the cells were rinsed with PBS and incubated with $10 \mu \mathrm{g} / \mathrm{ml}$ Hoechst 33342 for $10 \mathrm{~min}$. A fluorescence microscope was used to visualize the cells undergoing apoptosis, which display morphological alterations in the nucleus at $350 \mathrm{~nm}$.

Flow cytometric analysis of apoptosis. Apoptosis was measured by flow cytometric analysis, as previously described (22). Briefly, $2 \times 10^{5}$ cells/well PC-3 cells were seeded in 6-well plates and treated with $0-10 \mathrm{mg} / \mathrm{ml}$ GLP for 24 and $48 \mathrm{~h}$. Subsequently, the cells were collected and stained with $50 \mu \mathrm{g} / \mathrm{ml}$ Annexin V-FITC/PI at room temperature in the dark for $15 \mathrm{~min}$. Apoptosis was measured using a Guava ${ }^{\circledR}$ easyCyte flow cytometer system (Merck KGaA, Darmstadt, Germany). The ratio of Annexin $\mathrm{V}^{+} / \mathrm{PI}^{-}$(early) and Annexin $\mathrm{V}^{+} / \mathrm{PI}^{+}$(late) apoptotic cells was calculated.

Western blotting. Total protein was extracted from PC-3 cells using radioimmunoprecipitation assay buffer (Sigma-Aldrich; Merck KGaA) and protein concentrations were determined using the BCA method. Proteins $(35 \mu \mathrm{g})$ were separated by 10-12\% SDS-PAGE, and electrophoresed at $100 \mathrm{~V}$ for $2 \mathrm{~h}$. Separated proteins were transferred onto a polyvinylidene difluoride membrane at $100 \mathrm{~V}$ for $1 \mathrm{~h}$ on ice. After transfer, membranes were blocked with $5 \%$ non-fat dry milk in $1 \mathrm{X}$ Tris-buffered saline with Tween-20 $(50 \mathrm{mmol} / 1$ Tris, $\mathrm{pH} 7.5 ; 150 \mathrm{mmol} / \mathrm{l} \mathrm{NaCl} ; 0.1 \%$ Tween-20) at room temperature for $1 \mathrm{~h}$. The blots were subsequently incubated with primary antibodies $(1: 1,000)$ overnight at $4^{\circ} \mathrm{C}$. The blots were then incubated with the secondary antibody $(1: 2,000)$ at room temperature for $1 \mathrm{~h}$, according to the manufacturer's protocol. The signals were detected using the Western Lightning PlusECL Enhanced Chemiluminescence substrate (PerkinElmer, Inc.), according to the manufacturer's protocol. ImageJ 1.41 software (National Institutes of Health, Bethesda, MD, USA) was used to calculate the optical density.

Reverse transcription-quantitative polymerase chain reaction $(R T-q P C R)$. The quantity and quality of total RNA were assessed using a NanoDrop 2000 (Nanodrop Technologies; Thermo Fisher Scientific, Inc., Wilmington, DE, USA). A total of $1 \mu \mathrm{g}$ RNA was reverse transcribed to cDNA, using iScript cDNA Synthesis kit (Bio-Rad Laboratories, Inc.). The $\mathrm{RT}$ reaction was performed as follows $5 \mathrm{~min}$ at $25^{\circ} \mathrm{C}, 30 \mathrm{~min}$ at $42^{\circ} \mathrm{C}, 5 \mathrm{~min}$ at $85^{\circ} \mathrm{C}$. RT-qPCR analysis was performed using SYBR Master Mix (Bio-Rad Laboratories, Inc.) on a CFX96 Real-Time PCR system (Bio-Rad Laboratories, Inc.), according to the manufacturer's protocol. The PCR conditions consisted of 40 cycles, with $5 \mathrm{sec}$ denaturation at $95^{\circ} \mathrm{C}, 30 \mathrm{sec}$ annealing at $60^{\circ} \mathrm{C}$ and $5 \mathrm{sec}$ extension at $65^{\circ} \mathrm{C}$. The fold change in mRNA was calculated through relative quantification $\left(2^{-\Delta \Delta \mathrm{Cq}}\right)$ with $\beta$-actin used as the housekeeping gene (30). The primers used were as follows: $\beta$-actin, forward, 5'-CTGGAACGGTGAAGGTGACA-3' and reverse, 5'-AAGGAACTTCCTTGAACAATGCA-3'; NAG-1, forward, 5'-CTCCAGATTCCGAGAGTTGC-3' and reverse, 5'-AGAGATACGCAGGTGCAGGT-3'; and EGR-1, forward, 5'-AGCCCTACGAGCACCTGAC-3' and reverse, 5'-GGTTTGGCTGGGGTAACTG-3'.

RNA interference. NAG-1 RNA interference was conducted as previously described (31). Briefly, PC-3 cells were grown to $60 \%$ confluence and were transfected with $100 \mathrm{nM}$ NAG-1 siRNA or negative control siRNA overnight at $37^{\circ} \mathrm{C}$ using Lipofectamine ${ }^{\circledR} 2000$ reagent, according to the manufacturer's protocol. The effects of NAG-1siRNA were confirmed by western blot analysis. To determine the role of NAG-1 in the anticancer effects of GLP, following siRNA transfection overnight, the medium was removed, and PC-3 cells were washed with phosphate-buffered saline (PBS) and treated with $5 \mathrm{mg} / \mathrm{ml}$ GLP for up to $24 \mathrm{~h}$. The cells were subsequently harvested at $24 \mathrm{~h}$ and analyzed by western blotting and flow cytometry for the analysis of apoptosis.

Luciferase reporter assay. The human NAG-1 promoter construct used in the luciferase assay was previously described (32). Briefly, to generate pNAG-1 3'-untranslated region (UTR)-luciferase plasmid,NAG-1 3'-UTR was amplified using the following primers: forward, 5'-GGCCGATCTAGA GTTAACGCAGTCCTGGTCCTTCCACTGT-3' and reverse, 5'-GGCCGATCTAGAAAACAGTTCAGACAGCTTTATT-3' (XbaI sites are italicized). Subsequently, the amplified PCR product was digested with $X b a \mathrm{I}$ and ligated to the $\mathrm{Xba \textrm {I }}$ site positioned between luciferase and the SV polyadenylation site in the pGL3 promoter vector (Promega Corp.). For the luciferase assay, PC-3 cells were plated in 6-well plates at $2 \times 10^{5}$ cells/well in DMEM containing 10\% FBS. When cells reached a confluence of $50-60 \%$, plasmid mixture containing $1 \mu \mathrm{g}$ NAG-1 promoter linked to luciferase and $0.1 \mu \mathrm{g}$ pRLnull (Promega Corp.) were transfected using Lipofectamine ${ }^{\circledR}$ 2000 transfection reagent at $37^{\circ} \mathrm{C}$ for $24 \mathrm{~h}$, according to the manufacturer's protocol. Cells were then cultured in the absence or presence of 2.5 or $5 \mathrm{mg} / \mathrm{ml}$ GLP for an additional $24 \mathrm{~h}$. At the end of the study, the cells were collected and the 

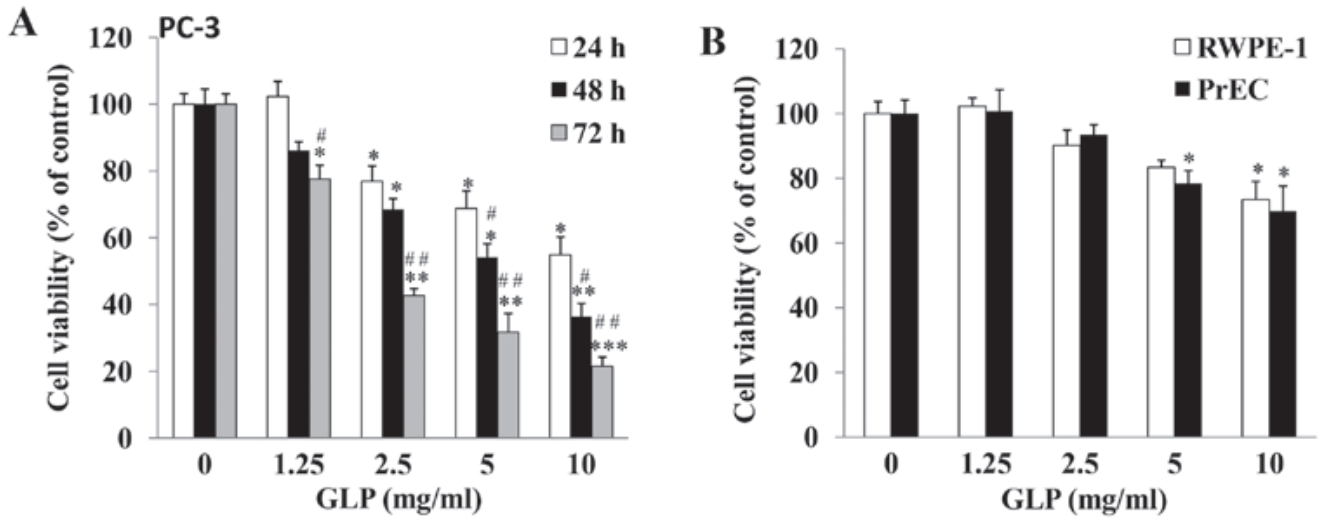

Figure 1. Effects of GLP on the viability of human prostate cancer PC-3 and non-cancerous RWPE-1 and PrEC cells. (A) GLP (1.25-10 mg/ml) inhibited the viability of PC-3 cells in a time-dependent manner (24, 48 and $72 \mathrm{~h}$ ). Data are presented as the means \pm standard error from three independent experiments. Two-way ANOVA with post hoc Bonferroni's correction for multiple comparisons was used to determine statistical significance. * indicates dose-dependent effects; \# indicates time-dependent effects. ${ }^{*} \mathrm{P}<0.05,{ }^{* * *} \mathrm{P}<0.01$ and ${ }^{* * * *} \mathrm{P}<0.001$ compared with untreated cells at each time-point. ${ }^{\#} \mathrm{P}<0.05$ and ${ }^{\# \#} \mathrm{P}<0.01$ compared with cells treated for $24 \mathrm{~h}$ with each concentration of GLP. (B) GLP at 5 and $10 \mathrm{mg} / \mathrm{ml}$ caused cytotoxicity in RWPE-1 and PrEC cells following treatment for $48 \mathrm{~h}$. Cell viability was examined using an MTT assay. Data are presented as the means \pm standard error. ${ }^{*} \mathrm{P}<0.05$; ${ }^{* *} \mathrm{P}<0.01$ compared with the control group (one-way ANOVA with Dunnett's correction). ANOVA, analysis of variance; GLP, Ganoderma lucidum polysaccharides.

Dual-Luciferase assay kit was used to measure luciferase activity, which was then normalized to the values of pRL-null luciferase activity.

ELISA. PC-3 cells were seeded in 6-well plates at $2 \times 10^{5}$ cells/well and incubated overnight. ELISA was performed when the cells had been treated with culture medium supplemented with GLP $(0-10 \mathrm{mg} / \mathrm{ml})$ for $48 \mathrm{~h}$ using cell culture medium at $37^{\circ} \mathrm{C}$. Cell lysates were also collected, and protein concentrations were measured by BCA assay to correct for variations. A Quantikine Human GDF15/NAG-1 ELISA kit was used to determine the expression of NAG-1 protein in the medium, according to the manufacturer's protocol, and the data were normalized to total protein concentration determined from the cell lysates.

Statistical analysis. Data are presented as the means \pm standard error of three independent experiments. Statistical analysis was performed using one-way analysis of variance (ANOVA) with Dunnett's correction for pairwise comparisons, or two-way ANOVA with post hoc Bonferroni's correction for multiple comparisons. $\mathrm{P}<0.05$ was considered to indicate a statistically significant difference. All analyses were performed using GraphPad Prism 5.0 software (GraphPad Software, Inc., La Jolla, CA, USA).

\section{Results}

GLP inhibits PC-3 cell viability in a dose-and timedependent manner. The growth inhibitory effects of GLP against PCa were examined. As determined by MTT assay, the viability of PC-3 cells was significantly reduced by GLP treatment in a dose- and time-dependent manner (Fig. 1A). PC-3 cells treated with $10 \mathrm{mg} / \mathrm{ml}$ GLP exhibited decreased cell viability compared with the control group; viability was decreased to $54.9 \pm 5.4,36.4 \pm 3.9$ and $21.5 \pm 2.8 \%$ at 24,48 and $72 \mathrm{~h}$, respectively $(\mathrm{P}<0.01)$, thus suggesting that GLP may be a potent anticancer agent against $\mathrm{PCa}$. In addition, the inhibitory effects of GLP on the viability of DU145 and LNCaP prostate cancer cells, which are also commonly used to study $\mathrm{PCa}$, were examined. The results demonstrated that GLP exerted similar effects to those observed in PC-3 cells (data not shown). Among these three cell lines, PC-3 and DU145 cells are androgen-independent cell lines, whereas $\mathrm{LNCaP}$ cells are androgen-dependent $(33,34)$. In addition, PC-3 cells demonstrate higher metastatic potential compared with DU145 cells (33). Due to the highly metastatic and androgenindependent properties of PC-3 cells, subsequent experiments only focused on the PC-3 cell line. It is well known that the majority of anticancer chemotherapy drugs additionally cause cytotoxicity in normal cells. Therefore, the present study investigated whether GLP exerted cytotoxic effects on normal prostate cells. As presented in Fig. 1B, following treatment of prostate non-malignant RWPE-1 and PrEC cells for $48 \mathrm{~h}$, GLP at lower concentrations $(1.25$ and $2.5 \mathrm{mg} / \mathrm{ml})$ did not cause significant cell death. However, GLP at 5 and $10 \mathrm{mg} / \mathrm{ml} \mathrm{did}$ cause cytotoxicity in RWPE-1 or PrEC cells. These results suggested that, similar to other natural anticancer compounds, the effects of GLP on PCa cancer cells are not cancer cellspecific.

GLP induces apoptosis of PC-3 cells. Hoechst 33342 staining was conducted to examine whether GLP induces apoptosis of PC-3 cells, which may be observed microscopically. Nuclear morphological alterations were observed, which indicated coagulation and fragmentation (indicated by a red circle), upon treatment of PC-3 cells with increasing concentrations of GLP (Fig. 2A). Subsequently, flow cytometry was used to further study the effects of GLP on apoptosis of PC-3 cells. It was observed that the amount of Annexin $\mathrm{V}^{+} / \mathrm{PI}^{+}$(late apoptosis) positive cells was significantly increased upon GLP treatment $(1.25-10 \mathrm{mg} / \mathrm{ml})$ in a dose- and time-dependent manner (Fig. 2B). However, GLP seemed to have no effect on early apoptosis, as there were no significant differences in the percentage of Annexin $\mathrm{V}^{+} / \mathrm{PI}^{-}$(early apoptosis) stained cells between treatment groups (Fig. 2B and C). The present data suggested that GLP may inhibit cell proliferation through the stimulation of late apoptosis in PC-3 cells. In addition, flow 
A
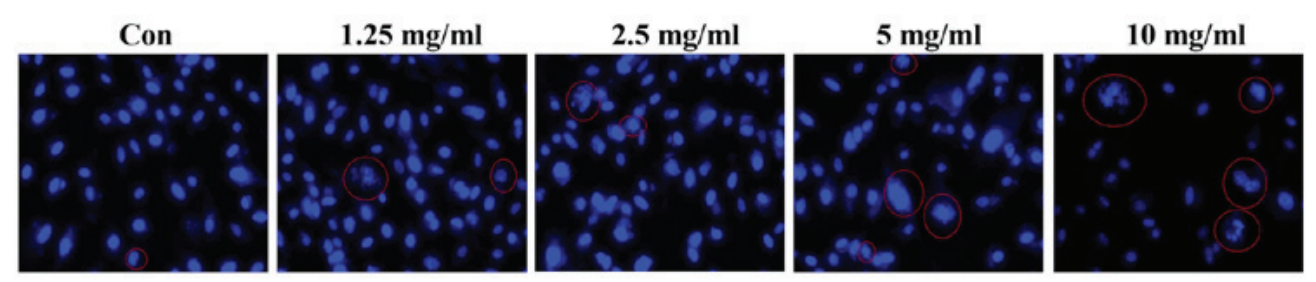

B
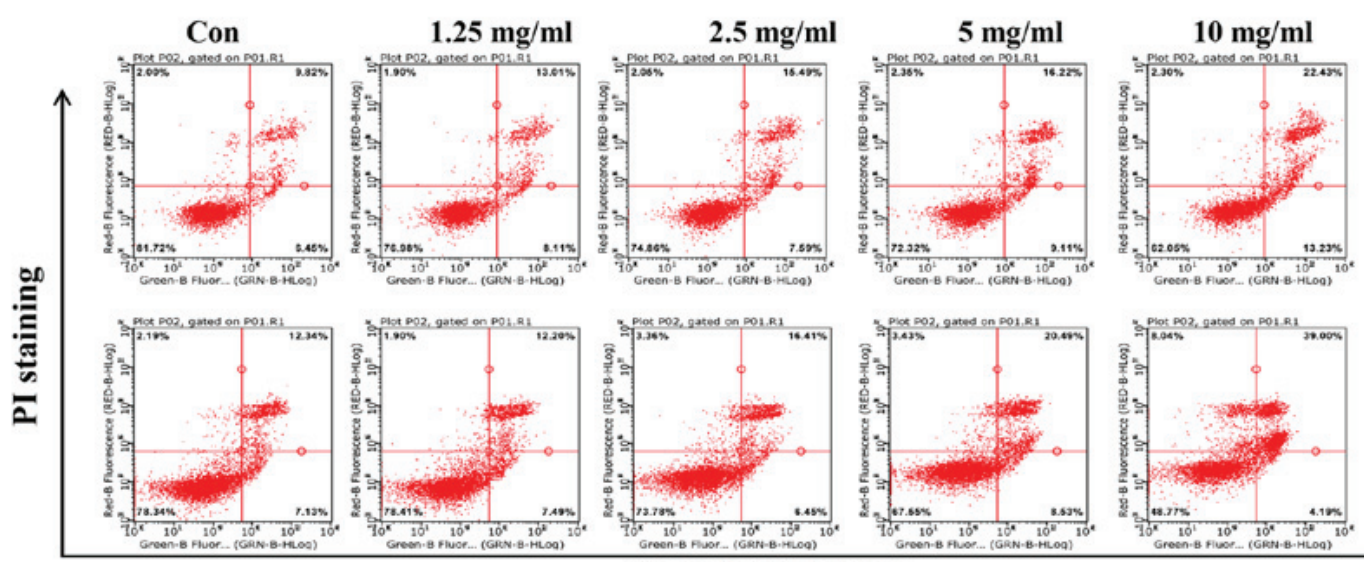

$24 \mathrm{~h}$
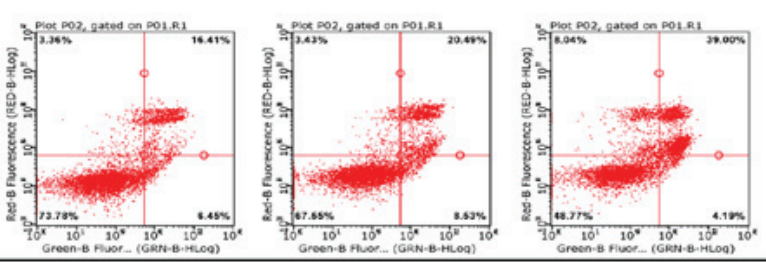

$48 \mathrm{~h}$

\section{Annexin V staining}
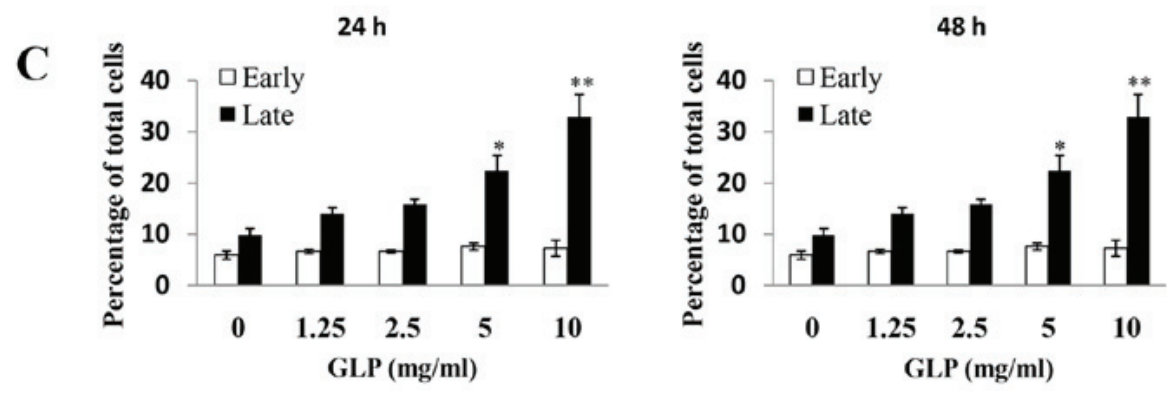

Figure 2. GLP induces apoptosis of PC-3 cells. (A) Cells were treated with various concentrations of GLP for $24 \mathrm{~h}$. Hoechst 33342 staining was used to analyze apoptotic cells. Magnification, 200x. (B) GLP $(0-10 \mathrm{mg} / \mathrm{ml})$ induced apoptosis of PC-3 cells at 24 and $48 \mathrm{~h}$. Apoptosis was quantified by Annexin V/fluorescein isothiocyanate flow cytometry. (C) Percentage of early and late apoptotic cells, as induced by GLP in PC-3 cells. Data are presented as the means \pm standard error of the mean. " $\mathrm{P}<0.05 ;{ }^{* *} \mathrm{P}<0.01$ compared with the control group (one-way analysis of variance with Dunnett's correction). GLP, Ganoderma lucidum polysaccharides; PI, propidium iodide.

cytometric analysis revealed that treatment with $10 \mathrm{mg} / \mathrm{ml}$ GLP slightly, but significantly, induced apoptosis of PWPE-1 and PrEC cells (data not shown), thus, suggesting a cytotoxic effect of GLP on normal cells.

Western blotting was subsequently conducted to examine the expression of key regulatory proteins associated with apoptosis in PC-3 cells upon GLP treatment (Fig. 3). The effects of $5 \mathrm{mg} / \mathrm{ml}$ GLP on the protein expression levels of pro-caspase-3, -6, -9 and PARP were examined at various time-points. As presented in Fig. 3A and C, the expression levels of the three pro-caspases were significantly downregulated between 6 and $48 \mathrm{~h}$ following GLP treatment. In addition, it was observed that cleaved PARP expression was markedly increased with time; however, the change in total PARP expression was not marked; this may have been due to the strong signals in the blot. The first control group (Con1) refers to when the protein sample was collected at $6 \mathrm{~h}$, whereas the second control group (Con2) refers to when the protein sample was collected at $48 \mathrm{~h}$. After $48 \mathrm{~h}$ of treatment, the protein expression levels of all pro-caspases and PARP in untreated cells (Con2) remained the same as at $6 \mathrm{~h}$ (Con1) (Fig. 3A). The dose-dependent effects of GLP on the regulation of these proteins were subsequently examined. Following treatment for $48 \mathrm{~h}$, GLP $(1.25-10 \mathrm{mg} / \mathrm{ml})$ inhibited the protein expression levels of pro-caspase-3, 6 and 9, although not in a precise dose-dependent manner (Fig. 3B). Conversely, the expression levels of full-length PARP were decreased, whereas cleaved PARP was increased, upon GLP treatment $(1.25-10 \mathrm{mg} / \mathrm{ml})$ in a dose-dependent manner (Fig. 3B). Taken together, these data indicated that GLP was effective at inducing apoptosis of PC-3 cells.

GLP induces EGR-1 and NAG-1 expression in PC-3 cells. Numerous studies have demonstrated that the expression of NAG-1 is induced by several natural compounds in cancer (32,35-38). A previous study suggested that EGR-1 may serve as an upstream factor for the induction of NAG-1expression (31). Our previous study recently reported that GLP is able to induce NAG-1 expression in colorectal cancer HCT116 cells (22). However, to the best of our knowledge, it remains unknown 
A

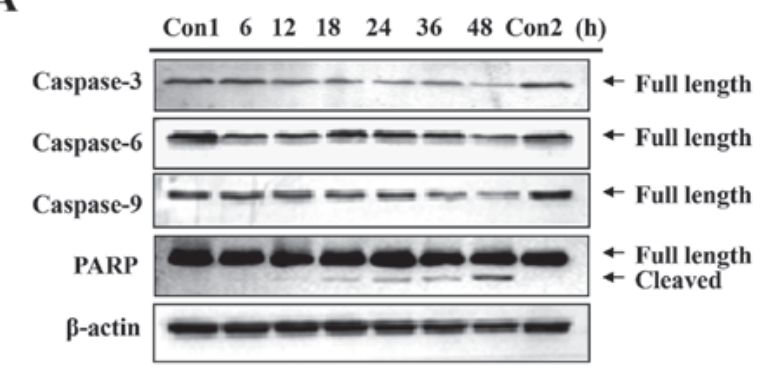

B

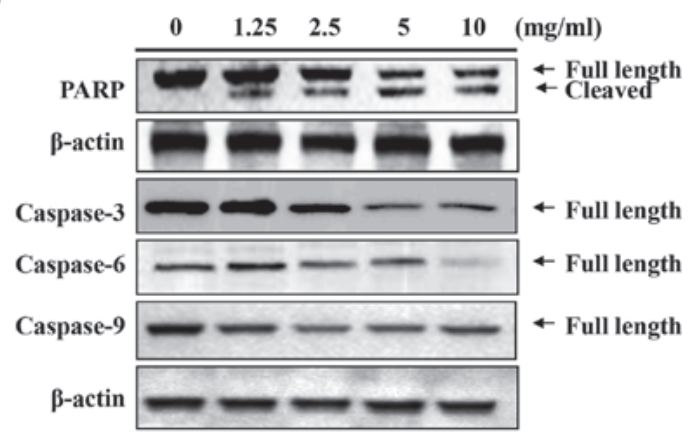

C
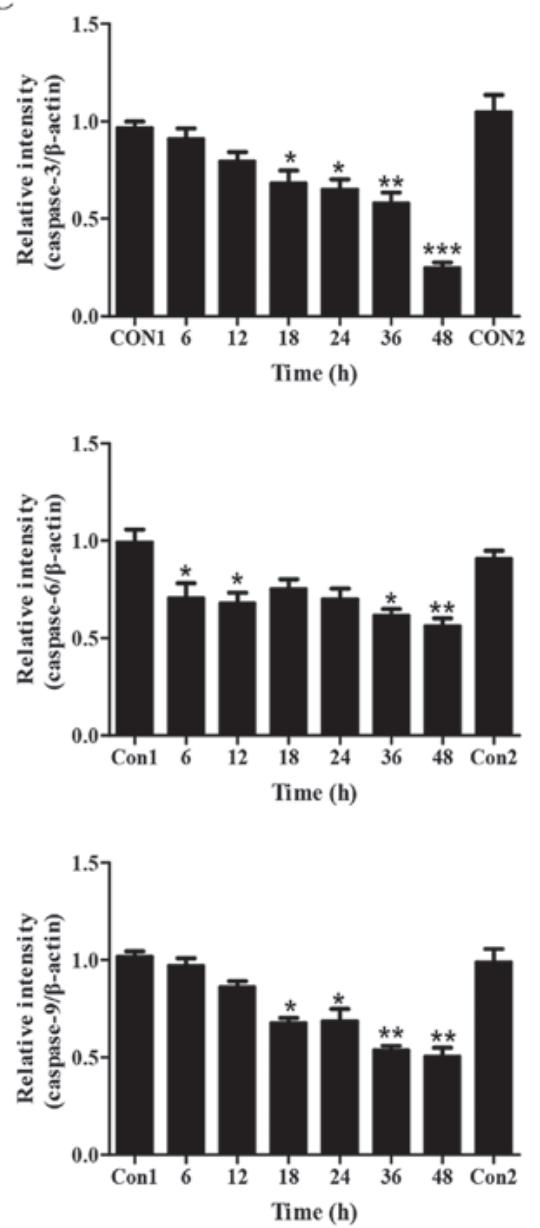

Figure 3. GLP induces PARP cleavage and inhibits the protein expression levels of pro-caspase-3, -6 and -9 in PC-3 cells. (A) Effects of GLP (5 mg/ml) on the protein expression levels of PARP and pro-caspase at various time-points $(6,12,18,24,36$ and $48 \mathrm{~h})$. Con1 indicates a sample collected at $6 \mathrm{~h}$ without GLP; Con 2 indicates a sample collected at $48 \mathrm{~h}$ without GLP. (B) Effects of various concentrations of GLP (0-10 mg/ml) on PARP and pro-caspase protein expression following treatment for $48 \mathrm{~h}$. Protein expression was determined by western blotting. $\beta$-actin was used as an internal control. (C) Expression levels of the three pro-caspases upon GLP treatment. Data are presented as the means \pm standard error of the mean. ${ }^{*} \mathrm{P}<0.05 ;{ }^{* * *} \mathrm{P}<0.01$ and ${ }^{* * *} \mathrm{P}<0.001$ compared with Con1 after normalization to $\beta$-actin (one-way analysis of variance with Dunnett's correction). GLP, Ganoderma lucidum polysaccharides; PARP, poly(ADP-ribose) polymerase.

as to whether NAG-1 and its upstream gene EGR-1 may be induced in PC-3 cells by GLP. To evaluate whether NAG-1 and EGR-1 were involved in the anticancer effects of GLP in PC-3 cells, the mRNA and protein expression levels of EGR-1 and NAG-1 were determined in PC-3 cells (Fig. 4A-D). Following exposure of the cells to $5 \mathrm{mg} / \mathrm{ml}$ GLP, the mRNA and protein expression levels of EGR-1 and NAG-1 were induced in a timedependent manner (Fig. 4A and C). The mRNA expression levels of EGR-1 and NAG-1 were significantly upregulated $6 \mathrm{~h}$ post-GLP treatment, and this effect reached its maximum at $18 \mathrm{~h}$ and was maintained at a high level until $24 \mathrm{~h}$ (Fig. 4A). The protein expression levels of EGR-1 were markedly upregulated at $12 \mathrm{~h}$ post-GLP treatment and the upregulation was maintained until $24 \mathrm{~h}$, whereas NAG-1 expression occurred later, with the highest expression detected at $24 \mathrm{~h}$ (Fig. 4C). The stimulation of EGR-1 and NAG-1 expression by various doses of GLP (1.25-10 mg/ml), following treatment for $24 \mathrm{~h}$, was also determined. As illustrated in Fig. 4B and D, the expression levels of EGR-1 and NAG-1 were induced by GLP in a dose-dependent manner at the mRNA and protein levels (Fig. 4B and 4D).
To determine whether GLP was able to directly activate the NAG-1 promoter, a luciferase reporter gene fused to the NAG-1 promoter was transfected into PC-3 cells, which were treated with GLP. GLP at 2.5 and $5 \mathrm{mg} / \mathrm{ml}$ significantly induced NAG-1 promoter activity by 1.9 and 3.5 -fold, respectively (Fig. 4E). In addition, the concentration of secreted NAG-1in the medium was measured by ELISA. Considering the cytotoxic effects caused by GLP treatment, the value determined from the ELISA was normalized to the total protein concentration in the cell lysates. It was observed that NAG-1 protein concentration was significantly increased in response to GLP treatment in a dose-dependent manner (Fig. 4F). Taken together, the present data indicated that GLP significantly induced expression of NAG-1 and its upstream factor EGR-1 in PC-3 cells.

GLP-induced apoptosis is mediated by NAG-1 induction . NAG-1 is a proapoptotic gene, and numerous studies have examined the role of NAG-1 in apoptosis (25-28). To link the anticancer effects of GLP to NAG-1 activation and its proapoptotic activity, PC-3 cells were transfected with 
A

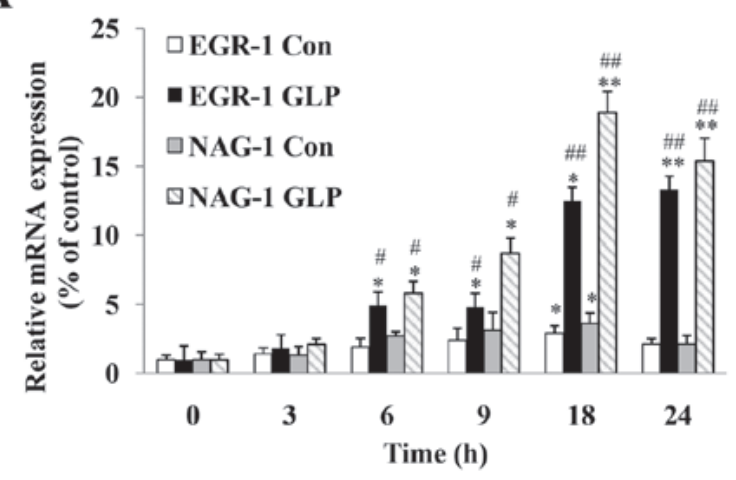

C

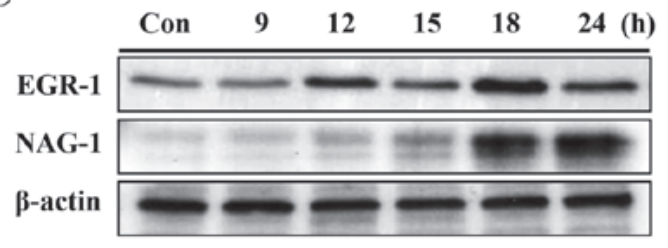

$\mathbf{E}$

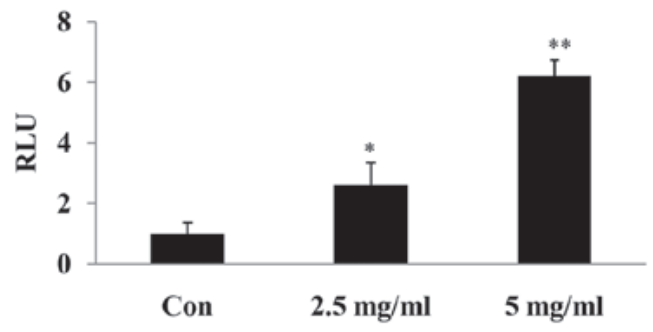

B

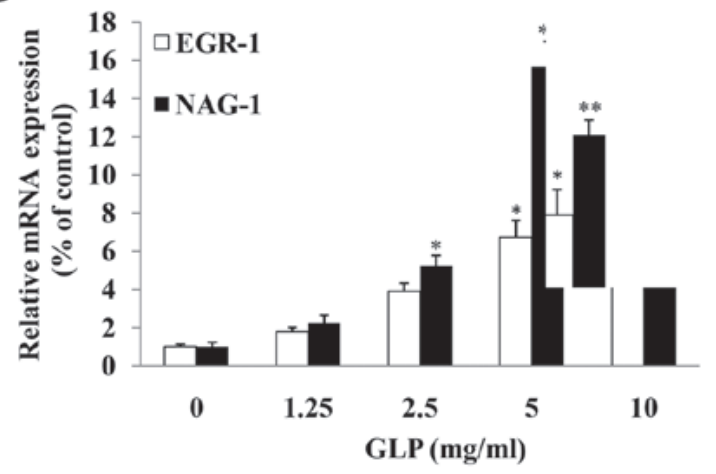

D

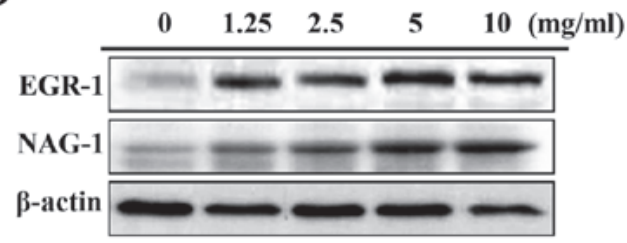

F

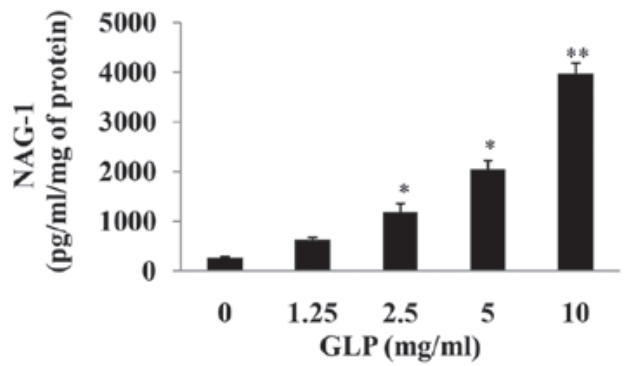

Figure 4. Expression levels of NAG-1, and its transcription factor EGR-1, are induced in PC-3 cells upon GLP treatment. (A) Quantification of the mRNA expression levels of NAG-1 and EGR-1 in a time-dependent manner (0-24 h) following treatment of PC-3 cells with 5 mg/ml GLP. Data are presented as the means \pm standard error from three independent experiments. Two-way ANOVA with post hoc Bonferroni's correction for multiple comparison was used to determine statistical significance. * indicates time-dependent effects; \# indicates effects of GLP treatment. * $\mathrm{P}<0.05$ and ${ }^{* *} \mathrm{P}<0.01$ compared with the $0 \mathrm{~h}$ group for each treatment. ${ }^{\#} \mathrm{P}<0.05$ and ${ }^{\# \#} \mathrm{P}<0.01$ compared with the untreated control group at each time-point. (B) Quantification of the mRNA expression levels of NAG-1 and EGR-1 in a dose-dependent manner following treatment of PC-3 cells with GLP (0-10 mg/ml) for 24 h. Induction of EGR-1 and NAG-1 protein expression upon GLP treatment in a (C) time-dependent and (D) dose-dependent manner, as determined by western blotting. $\beta$-actin was used as an internal control. (E) GLP induced NAG-1 promoter activity, as determined by luciferase assay. Fold-changes were normalized to pRL-null expressing Renilla luciferase protein. (F) ELISA of the concentration of NAG-1 protein in the cell culture medium following treatment with $0-10 \mathrm{mg} / \mathrm{ml}$ GLP for $48 \mathrm{~h}$. Data presented were normalized to the concentration of protein in lysates from each sample. All data are presented as the means \pm standard error of three independent experiments. ${ }^{*} \mathrm{P}<0.05,{ }^{* *} \mathrm{P}<0.01$ compared with the control group (one-way ANOVA with Dunnett's correction). ANOVA, analysis of variance; EGR-1, early growth response-1; GLP, Ganoderma lucidum polysaccharides; NAG-1, non-steroidal anti-inflammatory drug-activated gene-1; RLU, relative light units.

scrambled NAG-1 siRNA (vector) or NAG-1 siRNA, after which GLP-induced apoptosis was detected. As presented in Fig. 5A, western blotting confirmed the complete knockdown of NAG-1 expression in PC-3 cells, thus suggesting that the NAG-1 siRNA used was effective. The present study subsequently assessed whether GLP-induced NAG-1 expression was also inhibited by siRNA transfection. As demonstrated previously, NAG-1 expression was increased upon GLP treatment, whereas NAG-1 siRNA-transfected cells exhibited reduced GLP-induced NAG-1 expression (Fig. 5B). However, NAG-1 expression was not completely blocked. To examine whether NAG-1 serves a role in the induction of apoptosis by GLP, NAG-1 expression was knocked down and apoptosis was measured by flow cytometry. As displayed in Fig. 5C, GLP alone increased late apoptosis by 3.85 -fold compared with the control group $(\mathrm{P}<0.01)$. Conversely, apoptosis was significantly reduced in cells transfected with NAG-1 siRNA and treated with GLP, in which the percentage of late apoptosis was increased only by 1.68 -fold compared with NAG-1 siRNAtransfected cells (Fig. 5C; $\mathrm{P}<0.01$ ). There was a significant reduction in the late apoptosis of GLP and NAG-1 siRNAtransfected cells compared with in cells treated with GLP alone (Fig. 5C; P<0.01). However, GLP-induced apoptosis was not completely blocked by NAG-1 siRNA transfection, thus suggesting that NAG-1 induction is only partially responsible for GLP-induced apoptosis of PC-3 cells. The expression levels of the apoptosis-associated proteins, PARP and caspases, were detected following siRNA transfection by western blotting. As presented in Fig. 5D, the expression levels of pro-caspase-3, -6 and -9 (full length) were reduced upon GLP treatment; however, cells transfected with NAG-1 siRNA and treated with GLP exhibited a minimal reduction in the expression 
A

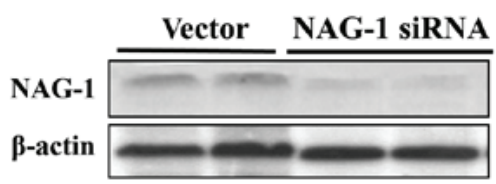

B

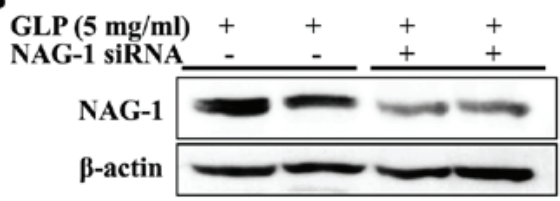

D

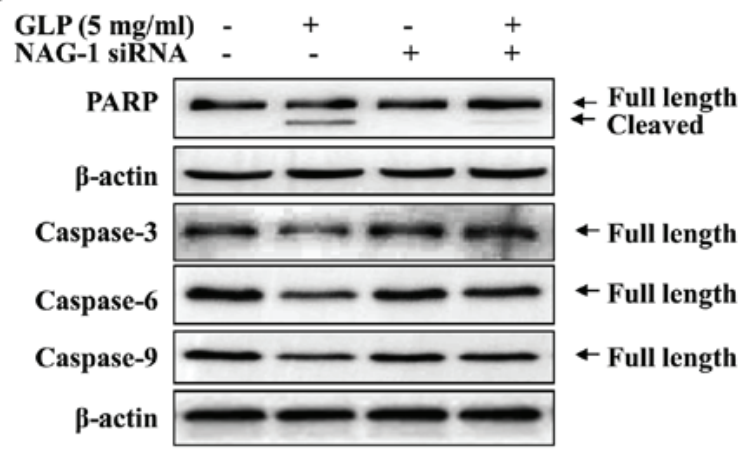

C

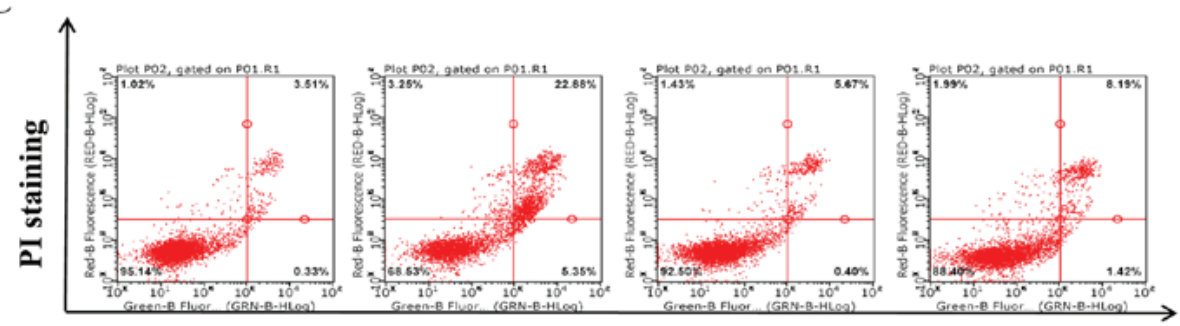

Annexin V staining

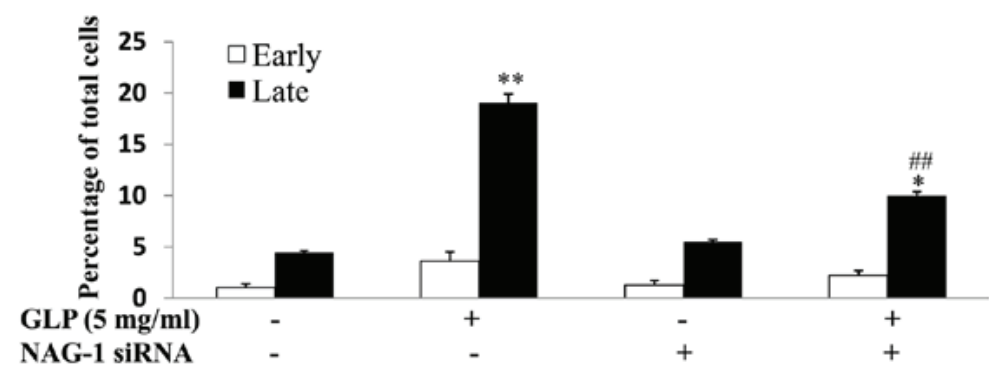

Figure 5. GLP-induced apoptosis of PC-3 cells is mediated through NAG-1 induction. (A) NAG-1 siRNA successfully knocked down NAG-1 expression in PC-3 cells, as determined by western blotting. (B) NAG-1 siRNA inhibited GLP-induced NAG-1 expression, as determined by western blotting. (C) NAG-1 siRNA inhibited GLP-induced apoptosis, as determined by flow cytometry. Percentage of early and late apoptotic of PC-3 cells induced by GLP is presented in the lower panel. (D) NAG-1 siRNA inhibited GLP-induced PARP cleavage and the suppression of pro-caspase-3, -6 and -9 protein expression. $\beta$-actin was used as an internal control. Data are presented as the means \pm standard error. ${ }^{*} \mathrm{P}<0.05,{ }^{* *} \mathrm{P}<0.01$ compared with the control group (one-way analysis of variance with Dunnett's correction). "P<0.01, compared with GLP-treated cells. GLP, Ganoderma lucidum polysaccharides; NAG-1, non-steroidal anti-inflammatory drug-activated gene-1; PARP, poly(ADP-ribose) polymerase; PI, propidium iodide; siRNA, small interfering RNA.

of these proteins (Fig. 5D). Similarly, GLP alone induced a reduction in pro-PARP and increased the induction of cleaved PARP, whereas NAG-1 siRNA abolished the induction of cleaved PARP (Fig. 5D). Taken together, these data supported the conclusion that GLP-induced apoptosis of PC-3 cells may be mediated, at least in part, by NAG-1 induction.

GLP inhibits mitogen-activated protein kinase $(M A P K) / E r k$ and Akt phosphorylation in PC-3 cells. The present study examined whether the MAPK/Erk and Akt signaling pathways may be regulated by GLP in PC-3 cells. As presented in Fig. 6A, $5 \mathrm{mg} / \mathrm{ml}$ GLP markedly reduced the phosphorylation of Akt and MAPK/Erk signaling from as early as $15 \mathrm{~min}$. In addition, GLP reduced the phosphorylation of Akt and MAPK/Erk proteins in a dose-dependent manner between 1.25 and $10 \mathrm{mg} / \mathrm{ml}$ (Fig. 6B). These data suggested that inhibition of MAPK/Erk and Akt activity may serve as a downstream signaling target of GLP in PC-3 cells; however, more definitive studies are required in the future to elucidate this association.

\section{Discussion}

During the late stages of the disease, $\mathrm{PCa}$ is characterized by the development of an androgen-refractory phenotype with a highly metastatic nature. Much effort has been made to identify novel therapies for the treatment of highly metastatic PCa. The use of TCM has received recognition in Western countries as an adjunct/alternative to conventional strategies for cancer therapy and prevention (39). Gaining an understanding of the molecular basis of TCM compounds and highlighting their potential applications for cancer treatment is crucial. Among the numerous TCM compounds, G. lucidum is one of the most widely studied for cancer prevention. The present study demonstrated that GLP from the broken spores of G. lucidum may be a potent inhibitor of $\mathrm{PCa}$ cell proliferation by inducing apoptosis of PC-3 cells, which was partially mediated by NAG-1 induction.

G. lucidum exerts numerous biological functions, including immunoregulatory, antiviral, antibacterial, antioxidant and hepatoprotective effects; in particular, its promising anticancer 
A

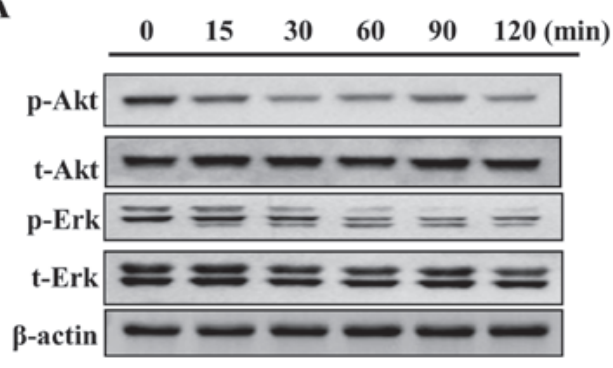

B

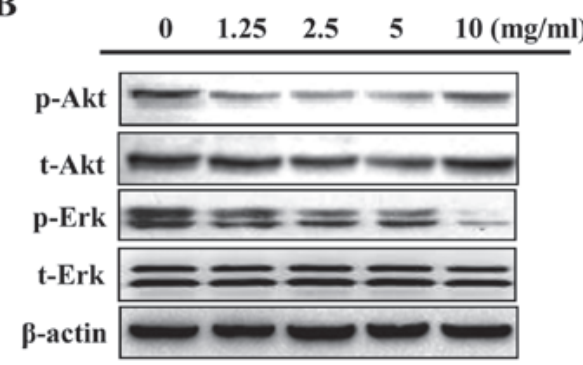

Figure 6. GLP inhibits the Akt and MAPK/Erk signaling pathway in PC-3 cells. (A) GLP $(5 \mathrm{mg} / \mathrm{ml})$ inhibited the phosphorylation of Akt and MAPK/Erk in a time-dependent manner in PC-3 cells. (B) GLP inhibited the phosphorylation of Akt and MAPK/Erk in a dose-dependent manner in PC-3 cells. $\beta$-actin was used as an internal control. Akt, protein kinase B; Erk, extracellular signal-regulated kinase; GLP, Ganoderma lucidum polysaccharides; MAPK, mitogen-activated protein kinase; $\mathrm{p}$-, phosphorylated; $t$, total.

activity has been reported $(19,40)$. The anticancer activities of GLP have remained a focus of interest for cancer prevention. Numerous studies have demonstrated that GLP is able to inhibit carcinogenesis in various types of cancer, including ovarian (41), lung $(42,43)$, breast (44), liver cancer (45), leukemia (46), colon cancer (22) and PCa (47). Amongst these cancer types, the anticancer effects of G. lucidum on PCa have been the most intensely investigated; this is due to earlier reports on PC-SPES and its anticancer activity in PCa. The first study was published in 1997, wherein Hsieh et al (48) reported that ethanol extracts of PC-SPES inhibit cell proliferation and reduce prostate specific antigen levels in $\mathrm{LNCaP}$ cells. Subsequently, clinical and laboratory studies have reported the potential activity of PC-SPES against hormone-independent PCa $(11,49)$.

Although PC-SPES was criticized for its adulteration of the Food and Drug Administration-controlled prescription drug synthetic estrogen diethylstilbestrol and warfarin, and was thus withdrawn from the market, the interest in G. lucidum as an individual TCM continues. Silva et al (21) reported that the spores and unpurified fruiting body of G. lucidum inhibit the constitutively active transcription factors activator protein-1 and nuclear factor- $\mathrm{\kappa B}$ in PC-3 cells, and thus suppress cell migration. Ethanol extracts from G. lucidum, containing ganoderic acid subtypes $\mathrm{F}$, have also been reported to inhibit cell proliferation of LNCaP cells and block hormone-induced prostate growth in castrated rats (50). Jiang et al (20) reported that G. lucidum extracts containing GLP and triterpenoids inhibit PC-3 cell proliferation in vitro. Further examination demonstrated that the growth inhibition of PC-3 cells mediated by G. lucidum is caused by dysregulation of the expression of cell cycle arrest-associated proteins (20). However, very few

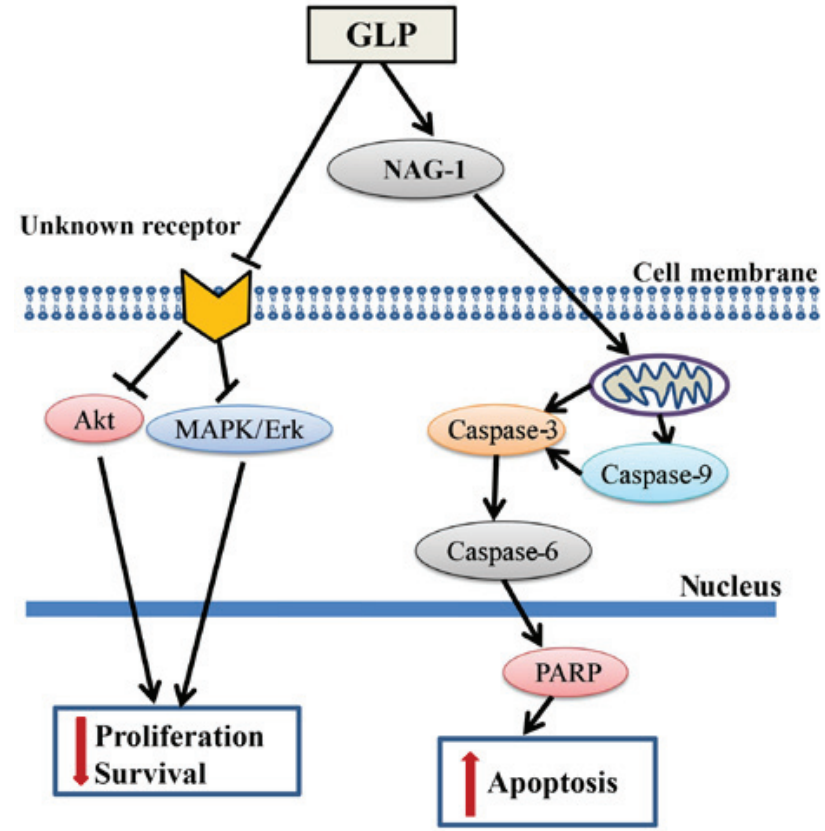

Figure 7. Working model of the molecular mechanisms by which GLP exerts its anticancer activity in prostate cancer PC-3 cells. GLP-induced apoptosis is mediated by NAG-1 induction, which may serve a pivotal role in GLPinduced cell death in prostate cancer cells.

of these studies have examined the effects of GLP, particularly those extracted from the broken spores of G. lucidum, against PCa. GLP is usually isolated from the fruiting bodies, mycelia and spores of G. lucidum (51). GLP isolated from the sporoderm-broken spores of G. lucidum may be more bioactive, exerting more potent cancer cell growth inhibitory effects compared with GLP isolated from other parts of G. lucidum $(22,52)$. The present study demonstrated that GLP from the sporoderm-broken spores of G. lucidum was a potent inhibitor of PCa PC-3 cell growth in a time- and dose-dependent manner. In the present study, the three most commonly used PCa cell lines, DU145, PC-3 and LNCaP, were assessed, and it was demonstrated that GLP was effective at inhibiting cell proliferation in all three cell lines. However, due to the highly metastatic and androgen-independent properties of PC-3 cells $(33,34)$, subsequent experiments focused on PC-3 cells.

Cancer is driven by an imbalance between cell proliferation and cell death (53). Apoptosis is a type of programmed cell death, which is regulated by a strict and complex signaling network that comprises a series of associated genes that must be coordinated $(53,54)$. In the present study, it was observed that GLP was effective at inducing apoptosis of PC-3 cells in a time- and dose-dependent manner. Notably, treatment with GLP at various concentrations did not induce early-stage apoptosis, although it significantly induced late-stage apoptosis of PC-3 cells. Numerous proteins regulate apoptosis; therefore, the expression of key regulatory proteins associated with apoptosis was detected. Caspases are important proteins for maintaining homeostasis by regulating cell death, and are key markers during apoptosis (55). The cleavage of caspases from their pro-form serves an important role in inducing apoptosis. The present study revealed that GLP downregulated the protein expression levels of pro-caspase $3,-6$ and -9 , and 
significantly cleaved PARP in PC-3 cells, as determined by western blotting.

Consistent with the present study, GLP has also been reported to induce apoptosis of other cancer cells, including breast (56) and colorectal cancer (57). Liang et al (57) reported that GLP-induced apoptosis of human colorectal cancer HCT116 cells is mediated by the activation of caspase-3 and -9 , and cleavage of PARP. In addition, a recent study demonstrated that GLP induces apoptosis of HCT116 cells by reducing total PARP, and pro-caspase-3 and -9 expression at the protein level (22). However, to the best of our knowledge, few studies have examined the proapoptotic activity of GLP in PCa cells. Zaidman et al (2) reported that G. lucidum ethanol extract, which primarily contains terpenoids, inhibits LNCaP cell proliferation by activating caspase- 3 and -8 , thus inducing cell apoptosis. In a previous study, it was demonstrated that GLP is also able to induce death receptor-mediated apoptosis through the induction of Fas-associated protein with death domain, tumor necrosis factor receptor-associated factor 2 and caspase- 8 expression in colorectal cancer xenograft tumors (22). It is well established that apoptosis is composed of two pathways: The extrinsic pathway, which is controlled by death receptors; and the intrinsic pathway, which is mediated by the mitochondria (58). Whether GLP may regulate the two apoptotic pathways in PCa cells requires further study.

NAG-1 is upregulated by several anticancer drugs, including NSAIDs, in addition to other dietary compounds, including resveratrol, epigallocatechin-3-gallate, genistein, conjugated linoleic acid, diallyl disulfide, green tea catechins and capsaicin $(23,59)$. Previously, it was demonstrated that NAG-1 expression is upregulated by GLP in colorectal cancer HCT116 cells and xenograft tumors at the mRNA and protein levels (22). However, whether GLP-induced apoptosis of HCT116 cells is mediated through NAG-1 induction has not been investigated. In the present study, using siRNA transfection, the role of NAG-1 in GLP-induced growth inhibition in PCa cells was determined. Notably, it was demonstrated that knocking down NAG-1 expression by siRNA significantly inhibited GLP-induced apoptosis of PC-3 cells. Furthermore, NAG-1 silencing inhibited the suppressive effects of GLP on the protein expression levels of pro-caspase 3, -6 and -9 , and inhibited PARP cleavage. These data suggested that NAG-1 may serve a pivotal role in GLP-induced apoptosis of PC-3 cells. Consistent with the present results, Shim and Eling (32) reported that vitamin $\mathrm{E}$ succinate treatment induces growth arrest and apoptosis, also mediated by NAG-1 induction, in PC-3 cells. Conjugated linoleic acid (CLA) has been reported to induce apoptosis and suppress cell proliferation in colorectal cancer HCT116 cells, and also to induce NAG-1 expression (60). In a previous study, inhibition of NAG-1 by siRNA was shown to result in the suppression of CLA-induced apoptosis of HCT116 cells (60); however, Chiu et al (61) demonstrated that NAG-1 induction by isochaihulactone causes isochaihulactone-induced cell cycle arrest, but not apoptosis, in LNCaP cells. Wynne et al (62) reported that NAG-1 induction is critical for NSAID-induced inhibition of cell migration in PCa cells, which is mediated by the p38 MAPK signaling pathway. Taken together, these findings suggest that NAG-1 induction by anticancer agents may target numerous cellular processes other than apoptosis.
Since the discovery of NAG-1, studies have examined its role in cancer development and progression. However, the results have been contradictory, with data from in vitro and in vivo studies suggesting an anticarcinogenic effect of NAG-1, whereas a protumorigenic or uncertain role of NAG-1 may be inferred from the clinical evidence. In particular, efforts have been made to establish the role of NAG-1 in PCa. Tan et al (63) demonstrated that NAG-1 causes growth arrest of DU145 cells, which may be the earliest report suggesting an anticancer effect of NAG-1 in PCa. Furthermore, overexpression of NAG-1 inhibits the growth of PC-3-bearing xenograft tumors (64). Husaini et al (24) crossed NAG-1 transgenic mice with transgenic adenocarcinoma of mouse prostate (TRAMP) mice, and observed that overexpression of NAG-1 in TRAMP mice significantly reduces tumor size and tumor grade compared within the TRAMP control mice. However, NAG-1-overexpressing TRAMP mice develop more distant organ metastases. In a parallel study, the same study group reported that deletion of the NAG-1 gene in TRAMP mice significantly promotes prostate tumor growth and increases the mortality rate of TRAMP mice (65). Collectively, in vivo and in vitro studies in general have suggested that NAG-1 exerts anticarcinogenic activity in $\mathrm{PCa}$.

Clinical evidence, however, does not support the idea of an antitumorigenic role for NAG-1 in PCa. Previous studies reported that the serum levels of NAG-1 are significantly increased in patients with cancer, including PCa $(66,67)$. Furthermore, NAG-1 levels in plasma are positively associated with PCa metastasis and tumor grade $(68,69)$. At present, the exact role of the increased secretion of NAG-1 in the plasma of patients with $\mathrm{PCa}$ is unknown. The mechanism underlying the paradoxical effects of NAG-1 in PCa from laboratory and clinical evidence is unclear at present and remains to be elucidated in future studies.

NAG-1 regulation at the transcriptional level has been extensively investigated by our group and others. The promoter region of NAG-1 has been well characterized, and a number of cis-acting and trans-acting elements, including Sp1 and two p53 tumor suppressor protein binding sites, have been identified (70). While certain studies have suggested that NSAIDs and natural compounds induce NAG-1 expression in a p53-dependent manner, others have reported that NAG-1 is induced in a p53-independent manner $(71,72)$. In the present study, GLP induced NAG-1 in p53-null PC-3 cells, thus suggesting a p53-independent mode of NAG-1 induction. EGR-1 has been demonstrated to act as a tumor suppressor gene, and its loss may lead to the progression of colorectal cancer (73). Studies have demonstrated that EGR-1exhibits its proapoptotic function by directly binding to the NAG-1 promoter $(28,31,74)$. Furthermore, it has been demonstrated that EGR-1 activates NAG-1 through interactions with the GC-rich proximal region of the NAG-1 promoter $(74,75)$. In the present study, the mRNA and protein levels expression of EGR-1 and NAG-1 were both induced by GLP in a timeand dose-dependent manner. Consistent with these results, a number of NSAIDs and peroxisome proliferator-activated receptor $\gamma$ ligands induce NAG-1 expression at the transcriptional level through the EGR-1 transcription factor (76,77). It has previously been reported that capsaicin and damnacanthal induce NAG-1 expression through the transcription factor 
CCAAT-enhancer-binding protein $\beta(78,79)$. Taken together, the transcriptional regulation of NAG-1 may be mediated by several mechanisms. Data from the present study suggested that NAG-1 was induced in PC-3 cells by upregulating the transcription factor EGR-1 in a p53-independent manner.

Signal transduction pathways serve an important role in carcinogenesis, and also serve as potential targets of chemopreventive agents. At present, the signaling pathways underlying the effects of GLP on cancer prevention remain poorly understood, although numerous studies have assessed the downstream signaling pathways of GLP. In the present study, it was observed that GLP inhibited the phosphorylation of MAPK/Erk and Akt in a time- and dose-dependent manner. The present data suggested that MAPK/Erk and Akt may serve as downstream signaling pathways of GLP in PCa. Akt is a downstream target of phosphoinositide 3-kinase (PI3K), and it has been well established that activation of the PI3K/Akt pathway serves an anti-apoptotic role in carcinogenesis (80). The MAPK cascade is a critical pathway for cancer cell survival, and Erk activation has been demonstrated to promote cancer cell proliferation (81). Yang et al (46) investigated the antitumor activity of GLP in HL-60 acute myeloid leukemia cells, and observed that GLP induces apoptosis of these cells. Furthermore, GLP blocks the MAPK/Erk pathway, and activates the p38 and c-Jun N-terminal kinase MAPK pathways (46). Together with the present study, further studies are required to clarify the signal transduction molecular targets of GLP, which may be associated with its anticancer effect.

In conclusion, the present study demonstrated that GLP significantly inhibited PCa cell proliferation via transcriptional upregulation of NAG-1 and downregulation of the MAPK/Erk and Akt signaling pathways (Fig. 7). The results of the present study identified NAG-1 as a molecular target of GLP-induced apoptosis, which may provide a novel approach for the study of GLP as an anticancer agent against PCa and other cancer types. To the best of our knowledge, this is the first study to demonstrate that GLP may inhibit the proliferation of PCa cells with the involvement of NAG-1 induction. However, the definitive role of NAG-1 in GLP-induced apoptosis and/or other cellular processes in $\mathrm{PCa}$ requires further examination in future studies.

\section{Acknowledgements}

Not applicable.

\section{Funding}

The present study was supported by the National Natural Science Foundation of China (grant no. 81473397).

\section{Availability of data and materials}

The datasets used and/or analyzed during the current study are available from the corresponding author on reasonable request.

\section{Authors' contributions}

$\mathrm{KW}$ performed the majority of the study and wrote the manuscript. KN conducted the flow cytometry assay. DC, YW and
HP helped with GLP extraction and purification. XW designed the experiments and edited the manuscript.

\section{Ethics approval and consent to participate}

Not applicable.

\section{Patient consent for publication}

Not applicable.

\section{Competing interests}

The authors declare that they have no competing interests.

\section{References}

1. Siegel RL, Miller KD and Jemal A: Cancer Statistics, 2017. CA Cancer J Clin 67: 7-30, 2017.

2. Zaidman BZ, Wasser SP, Nevo E and Mahajna J: Androgen receptor-dependent and -independent mechanisms mediate Ganoderma lucidum activities in LNCaP prostate cancer cells. Int J Oncol 31: 959-967, 2007.

3. Baillargeon J, Platz EA, Rose DP, Pollock BH, Ankerst DP, Haffner S, Higgins B, Lokshin A, Troyer D, Hernandez J, et al: Obesity, adipokines, and prostate cancer in a prospective population-based study. Cancer Epidemiol Biomarkers Prev 15: 1331-1335, 2006.

4. Hettel D and Sharifi N: HSD3B1 status as a biomarker of androgen deprivation resistance and implications for prostate cancer. Nat Rev Urol 15: 191-196, 2017.

5. Feldman BJ and Feldman D: The development of androgenindependent prostate cancer. Nat Rev Cancer 1: 34-45, 2001.

6. Mahajna J, Dotan N, Zaidman BZ, Petrova RD and Wasser SP: Pharmacological values of medicinal mushrooms for prostate cancer therapy: The case of Ganoderma lucidum. Nutr Cancer 61: 16-26, 2009.

7. Bigler D, Gulding KM, Dann R, Sheabar FZ, Conaway MR and Theodorescu D: Gene profiling and promoter reporter assays: Novel tools for comparing the biological effects of botanical extracts on human prostate cancer cells and understanding their mechanisms of action. Oncogene 22: 1261-1272, 2003.

8. Darzynkiewicz Z, Traganos F, Wu JM and Chen S: Chinese herbal mixture PC SPES in treatment of prostate cancer (Review). Int J Oncol 17: 729-736, 2000.

9. Halicka H, Ardelt B, Juan G, Mittelman A, Chen S, Traganos F and Darzynkiewicz Z: Apoptosis and cell cycle effects induced by extracts of the Chinese herbal preparation PC SPES. Int J Oncol 11: 437-448, 1997.

10. Kubota T, Hisatake J, Hisatake Y, Said JW, Chen SS, Holden S, Taguchi $\mathrm{H}$ and Koeffler HP: PC-SPES: A unique inhibitor of proliferation of prostate cancer cells in vitro and in vivo. Prostate 42: 163-171, 2000.

11. de la Taille A, Hayek OR, Burchardt M, Burchardt T and Katz AE: Role of herbal compounds (PC-SPES) in hormone-refractory prostate cancer: Two case reports. J Altern Complement Med 6: 449-451, 2000.

12. de la Taille A, Hayek OR, Buttyan R, Bagiella E, Burchardt M and Katz AE: Effects of a phytotherapeutic agent, PC-SPES, on prostate cancer: A preliminary investigation on human cell lines and patients. BJU Int 84: 845-850, 1999.

13. DiPaola RS, Zhang H, Lambert GH, Meeker R, Licitra E, Rafi MM, Zhu BT, Spaulding H, Goodin S, Toledano MB, et al: Clinical and biologic activity of an estrogenic herbal combination (PC-SPES) in prostate cancer. N Engl J Med 339: 785-791, 1998.

14. Pfeifer BL, Pirani JF, Hamann SR and Klippel KF: PC-SPES, a dietary supplement for the treatment of hormone-refractory prostate cancer. BJU Int 85: 481-485, 2000.

15. Pirani JF: The effects of phytotherapeutic agents on prostate cancer: An overview of recent clinical trials of PC SPES. Urology 58 (Suppl 1): 36-38, 2001. 
16. Small EJ, Frohlich MW, Bok R, Shinohara K, Grossfeld G, Rozenblat Z, Kelly WK, Corry M and Reese DM: Prospective trial of the herbal supplement PC-SPES in patients with progressive prostate cancer. J Clin Oncol 18: 3595-3603, 2000.

17. Chaudhary UB, Rashid M and Keane TE: PC-SPES withdrawal response. Acta Oncol 43: 772-773, 2004.

18. Cordell GA: PC-SPES: A brief overview. Integr Cancer Ther 1: 271-286, 2002.

19. Bishop KS, Kao CH, Xu Y, Glucina MP, Paterson RR and Ferguson LR: From 2000years of Ganoderma lucidum to recent developments in nutraceuticals. Phytochemistry 114: 56-65, 2015.

20. Jiang J, Slivova V, Valachovicova T, Harvey K and Sliva D: Ganoderma lucidum inhibits proliferation and induces apoptosis in human prostate cancer cells PC-3. Int J Oncol 24: 1093-1099, 2004.

21. Sliva D, Labarrere C, Slivova V, Sedlak M, Lloyd FP Jr and Ho NW: Ganoderma lucidum suppresses motility of highly invasive breast and prostate cancer cells. Biochem Biophys Res Commun 298: 603-612, 2002.

22. Na K, Li K, Sang T, Wu K, Wang Y and Wang X: Anticarcinogenic effects of water extract of sporoderm-broken spores of Ganoderma lucidum on colorectal cancer in vitro and in vivo. Int J Oncol 50: 1541-1554, 2017.

23. Wang X, Baek SJ and Eling TE: The diverse roles of nonsteroidal anti-inflammatory drug activated gene (NAG-1/GDF15) in cancer. Biochem Pharmacol 85: 597-606, 2013.

24. Husaini Y, Qiu MR, Lockwood GP, Luo XW, Shang P, Kuffner T, Tsai VW, Jiang L, Russell PJ, Brown DA, et al: Macrophage inhibitory cytokine-1 (MIC-1/GDF15) slows cancer development but increases metastases in TRAMP prostate cancer prone mice. PLoS One 7: e43833, 2012.

25. Piyanuch R, Sukhthankar M, Wandee G and Baek SJ: Berberine, a natural isoquinoline alkaloid, induces NAG-1 and ATF3 expression in human colorectal cancer cells. Cancer Lett 258: 230-240, 2007.

26. Kang SU, Shin YS, Hwang HS, Baek SJ, Lee SH and Kim CH: Tolfenamic acid induces apoptosis and growth inhibition in head and neck cancer: Involvement of NAG-1 expression. PLoS One 7: e34988, 2012

27. Tesei A, Rosetti M, Ulivi P, Fabbri F, Medri L, Vannini I, Bolla M, Amadori D and Zoli W: Study of molecular mechanisms of proapoptotic activity of NCX 4040, a novel nitric oxide-releasing aspirin, in colon cancer cell lines. J Transl Med 5: 52, 2007.

28. Woo SM, Min KJ, Kim S, Park JW, Kim DE, Chun KS, Kim YH, Lee TJ, Kim SH, Choi YH, et al: Silibinin induces apoptosis of HT29 colon carcinoma cells through early growth response- 1 (EGR-1)-mediated non-steroidal anti-inflammatory drugactivated gene-1 (NAG-1) up-regulation. Chem Biol Interact 211: 36-43, 2014.

29. Baek SJ, Kim KS, Nixon JB, Wilson LC and Eling TE: Cyclooxygenase inhibitors regulate the expression of a TGF-beta superfamily member that has proapoptotic and antitumorigenic activities. Mol Pharmacol 59: 901-908, 2001.

30. Livak KJ and Schmittgen TD: Analysis of relative gene expression data using real-time quantitative PCR and the 2(-Delta Delta C(T)) Method. Methods 25: 402-408, 2001

31. Yoshioka $\mathrm{H}$, Kamitani $\mathrm{H}$, Watanabe T and Eling TE: Nonsteroidal anti-inflammatory drug-activated gene (NAG-1/GDF15) expression is increased by the histone deacetylase inhibitor trichostatin A. J Biol Chem 283: 33129-33137, 2008.

32. Shim $M$ and Eling TE: Vitamin E succinate induces NAG-1 expression in a p38 kinase-dependent mechanism. Mol Cancer Ther 7: 961-971, 2008

33. Dillard PR, Lin MF and Khan SA: Androgen-independent prostate cancer cells acquire the complete steroidogenic potential of synthesizing testosterone from cholesterol. Mol Cell Endocrinol 295: 115-120, 2008.

34. Tai S, Sun Y, Squires JM, Zhang H, Oh WK, Liang CZ and Huang J: PC3 is a cell line characteristic of prostatic small cell carcinoma. Prostate 71: 1668-1679, 2011.

35. Auyeung KK, Cho CH and Ko JK: A novel anticancer effect of Astragalus saponins: Transcriptional activation of NSAIDactivated gene. Int J Cancer 125: 1082-1091, 2009.

36. Baek SJ, Kim JS, Jackson FR, Eling TE, McEntee MF and Lee SH: Epicatechin gallate-induced expression of NAG-1 is associated with growth inhibition and apoptosis in colon cancer cells. Carcinogenesis 25: 2425-2432, 2004.
37. Jutooru I, Chadalapaka G, Chintharlapalli S, Papineni S and Safe S: Induction of apoptosis and nonsteroidal anti-inflammatory drug-activated gene 1 in pancreatic cancer cells by a glycyrrhetinic acid derivative. Mol Carcinog 48: 692-702, 2009.

38. Soto-Cerrato V, Viñals F, Lambert JR, Kelly JA and Pérez-Tomás R: Prodigiosin induces the proapoptotic gene NAG-1 via glycogen synthase kinase-3beta activity in human breast cancer cells. Mol Cancer Ther 6: 362-369, 2007.

39. Li K, Na K, Sang T, Wu K, Wang Y and Wang X: The ethanol extracts of sporoderm-broken spores of Ganoderma lucidum inhibit colorectal cancer in vitro and in vivo. Oncol Rep 38: 2803-2813, 2017.

40. Kladar NV, Gavarić NS and Božin BN: Ganoderma: Insights into anticancer effects. Eur J Cancer Prev 25: 462-471, 2016.

41. Hsieh TC and Wu JM: Suppression of proliferation and oxidative stress by extracts of Ganoderma lucidum in the ovarian cancer cell line OVCAR-3. Int J Mol Med 28: 1065-1069, 2011.

42. Cao QZ and Lin ZB: Ganoderma lucidum polysaccharides peptide inhibits the growth of vascular endothelial cell and the induction of VEGF in human lung cancer cell. Life Sci 78: 1457-1463, 2006.

43. Gill BS, Navgeet and Kumar S: Ganoderma lucidum targeting lung cancer signaling: A review. Tumour Biol 39: 1010428317707437, 2017. doi: 10.1177/1010428317707437.

44. Loganathan J, Jiang J, Smith A, Jedinak A, Thyagarajan-Sahu A, Sandusky GE, Nakshatri $\mathrm{H}$ and Sliva D: The mushroom Ganoderma lucidum suppresses breast-to-lung cancer metastasis through the inhibition of pro-invasive genes. Int J Oncol 44: 2009-2015, 2014

45. Li A, Shuai X, Jia Z, Li H, Liang X, Su D and Guo W: Ganoderma lucidum polysaccharide extract inhibits hepatocellular carcinoma growth by downregulating regulatory $\mathrm{T}$ cells accumulation and function by inducing microRNA-125b. J Transl Med 13: 100, 2015.

46. Yang G, Yang L, Zhuang Y, Qian X and Shen Y: Ganoderma lucidum polysaccharide exerts anti-tumor activity via MAPK pathways in HL-60 acute leukemia cells. J Recept Signal Transduct Res 36: 6-13, 2016.

47. Zhao X, Zhou D, Liu Y, Li C, Zhao X, Li Y and Li W: Ganoderma lucidum polysaccharide inhibits prostate cancer cell migration via the protein arginine methyltransferase 6 signaling pathway. Mol Med Rep 17: 147-157, 2018.

48. Hsieh T, Chen SS, Wang X and Wu JM: Regulation of androgen receptor (AR) and prostate specific antigen (PSA) expression in the androgen-responsive human prostate $\mathrm{LNCaP}$ cells by ethanolic extracts of the Chinese herbal preparation, PC-SPES Biochem Mol Biol Int 42: 535-544, 1997.

49. Geliebter J, Tiwari R and Wu JM: PC-SPES in prostate cancer. N Engl J Med 340: 567-568, 1999.

50. Liu J, Tamura S, Kurashiki K, Shimizu K, Noda K, Konishi F, Kumamoto S and Kondo R: Anti-androgen effects of extracts and compounds from Ganoderma lucidum. Chem Biodivers 6: 231-243, 2009.

51. Ferreira IC, Heleno SA, Reis FS, Stojkovic D, Queiroz MJ, Vasconcelos MH and Sokovic M: Chemical features of Ganoderma polysaccharides with antioxidant, antitumor and antimicrobial activities. Phytochemistry 114: 38-55, 2015.

52. Guo L, Xie J, Ruan Y, Zhou L, Zhu H, Yun X, Jiang Y, Lü L, Chen K, Min Z, et al: Characterization and immunostimulatory activity of a polysaccharide from the spores of Ganoderma lucidum. Int Immunopharmacol 9: 1175-1182, 2009.

53. Hanahan D and Weinberg RA: Hallmarks of cancer: The next generation. Cell 144: 646-674, 2011.

54. Fuchs Y and Steller H: Programmed cell death in animal development and disease. Cell 147: 742-758, 2011.

55. McIlwain DR, Berger T and Mak TW: Caspase functions in cell death and disease. Cold Spring Harb Perspect Biol 7: 7, 2015.

56. Shang D, Li Y, Wang C, Wang X, Yu Z and Fu X: A novel polysaccharide from Se-enriched Ganoderma lucidum induces apoptosis of human breast cancer cells. Oncol Rep 25: 267-272, 2011.

57. Liang Z, Yi Y, Guo Y, Wang R, Hu Q and Xiong X: Chemical characterization and antitumor activities of polysaccharide extracted from Ganoderma lucidum. Int J Mol Sci 15: 9103-9116, 2014.

58. Dasgupta A, Nomura M, Shuck R and Yustein J: Cancer's Achilles' Heel: Apoptosis and necroptosis to the rescue. Int J Mol Sci 18: 18, 2016. 
59. Liggett JL, Zhang X, Eling TE and Baek SJ: Anti-tumor activity of non-steroidal anti-inflammatory drugs: Cyclooxygenaseindependent targets. Cancer Lett 346: 217-224, 2014.

60. Lee SH, Yamaguchi K, Kim JS, Eling TE, Safe S, Park Y and Baek SJ: Conjugated linoleic acid stimulates an anti-tumorigenic protein NAG-1 in an isomer specific manner. Carcinogenesis 27: 972-981, 2006.

61. Chiu SC, Wang MJ, Yang HH, Chen SP, Huang SY, Chen YL, Lin SZ, Harn HJ and Pang CY: Activation of NAG-1 via JNK signaling revealed an isochaihulactone-triggered cell death in human LNCaP prostate cancer cells. BMC Cancer 11: 146, 2011.

62. Wynne S and Djakiew D: NSAID inhibition of prostate cancer cell migration is mediated by Nag-1 Induction via the p38 MAPK-p75(NTR) pathway. Mol Cancer Res 8: 1656-1664, 2010.

63. Tan M, Wang Y, Guan K and Sun Y: PTGF-beta, a type beta transforming growth factor (TGF-beta) superfamily member, is a p53 target gene that inhibits tumor cell growth via TGF-beta signaling pathway. Proc Natl Acad Sci USA 97: 109-114, 2000.

64. Lambert JR, Kelly JA, Shim M, Huffer WE, Nordeen SK, Baek SJ, Eling TE and Lucia MS: Prostate derived factor in human prostate cancer cells: Gene induction by vitamin D via a p53-dependent mechanism and inhibition of prostate cancer cell growth. J Cell Physiol 208: 566-574, 2006.

65. Husaini Y,Lockwood GP, Nguyen TV, Tsai VW, Mohammad MG, Russell PJ, Brown DA and Breit SN: Macrophage inhibitory cytokine-1 (MIC-1/GDF15) gene deletion promotes cancer growth in TRAMP prostate cancer prone mice. PLoS One 10: e0115189, 2015.

66. Brown DA, Ward RL, Buckhaults P, Liu T, Romans KE, Hawkins NJ, Bauskin AR, Kinzler KW, Vogelstein B and Breit SN: MIC-1 serum level and genotype: Associations with progress and prognosis of colorectal carcinoma. Clin Cancer Res 9: 2642-2650, 2003

67. Welsh JB, Sapinoso LM, Kern SG, Brown DA, Liu T, Bauskin AR, Ward RL, Hawkins NJ, Quinn DI, Russell PJ, et al: Large-scale delineation of secreted protein biomarkers overexpressed in cancer tissue and serum. Proc Natl Acad Sci USA 100: 34103415,2003

68. Selander KS, Brown DA, Sequeiros GB, Hunter M, Desmond R, Parpala T, Risteli J, Breit SN and Jukkola-Vuorinen A: Serum macrophage inhibitory cytokine-1 concentrations correlate with the presence of prostate cancer bone metastases. Cancer Epidemiol Biomarkers Prev 16: 532-537, 2007.

69. Senapati S, Rachagani S, Chaudhary K, Johansson SL, Singh RK and Batra SK: Overexpression of macrophage inhibitory cytokine-1 induces metastasis of human prostate cancer cells through the FAK-RhoA signaling pathway. Oncogene 29: 12931302,2010

70. Baek SJ, Horowitz JM and Eling TE: Molecular cloning and characterization of human nonsteroidal anti-inflammatory drugactivated gene promoter. Basal transcription is mediated by Sp1 and Sp3. J Biol Chem 276: 33384-33392, 2001.
71. Kang SU, Lee BS, Lee SH, Baek SJ, Shin YS and Kim CH: Expression of NSAID-activated gene-1 by EGCG in head and neck cancer: Involvement of ATM-dependent p53 expression. J Nutr Biochem 24: 986-999, 2013.

72. Zhong Y, Krisanapun C, Lee SH, Nualsanit T, Sams C, Peungvicha $\mathrm{P}$ and Baek SJ: Molecular targets of apigenin in colorectal cancer cells: Involvement of p21, NAG-1 and p53. Eur J Cancer 46: 3365-3374, 2010.

73. Krones-Herzig A, Mittal S, Yule K, Liang H, English C, Urcis R, Soni T, Adamson ED and Mercola D: Early growth response 1 acts as a tumor suppressor in vivo and in vitro via regulation of p53. Cancer Res 65: 5133-5143, 2005.

74. Baek SJ, Kim JS, Moore SM, Lee SH, Martinez J and Eling TE: Cyclooxygenase inhibitors induce the expression of the tumor suppressor gene EGR-1, which results in the up-regulation of NAG-1, an antitumorigenic protein. Mol Pharmacol 67: 356-364, 2005.

75. Lim JH, Park JW, Min DS, Chang JS, Lee YH, Park YB, Choi KS and Kwon TK: NAG-1 up-regulation mediated by EGR-1 and p53 is critical for quercetin-induced apoptosis in HCT116 colon carcinoma cells. Apoptosis 12: 411-421, 2007.

76. Baek SJ, Wilson LC, Hsi LC and Eling TE: Troglitazone, a peroxisome proliferator-activated receptor gamma (PPAR gamma) ligand, selectively induces the early growth response-1 gene independently of PPAR gamma. A novel mechanism for its anti-tumorigenic activity. J Biol Chem 278: 5845-5853, 2003.

77. Chintharlapalli S, Papineni S, Baek SJ, Liu S and Safe S: 1,1-Bis(3'-indolyl)-1-(p-substitutedphenyl)methanes are peroxisome proliferator-activated receptor gamma agonists but decrease HCT-116 colon cancer cell survival through receptor-independent activation of early growth response-1 and nonsteroidal anti-inflammatory drug-activated gene-1. Mol Pharmacol 68: 1782-1792, 2005.

78. Lee SH, Krisanapun C and Baek SJ: NSAID-activated gene-1 as a molecular target for capsaicin-induced apoptosis through a novel molecular mechanism involving GSK3beta, C/EBPbeta and ATF3. Carcinogenesis 31: 719-728, 2010.

79. Nualsanit T, Rojanapanthu P, Gritsanapan W, Lee SH, Lawson D and Baek SJ: Damnacanthal, a noni component, exhibits antitumorigenic activity in human colorectal cancer cells. J Nutr Biochem 23: 915-923, 2012.

80. Vivanco I and Sawyers CL: The phosphatidylinositol 3-Kinase AKT pathway in human cancer. Nat Rev Cancer 2: 489-501, 2002.

81. Burotto M, Chiou VL, Lee JM and Kohn EC: The MAPK pathway across different malignancies: A new perspective. Cancer 120: 3446-3456, 2014.

This work is licensed under a Creative Commons Attribution-NonCommercial-NoDerivatives 4.0 International (CC BY-NC-ND 4.0) License. 